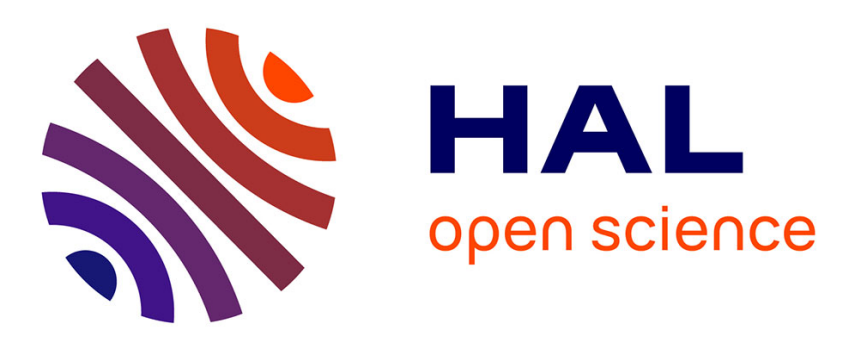

\title{
French public management reform: an evaluation
}

Gilles Jeannot, Danièle Guillemot

\section{To cite this version:}

Gilles Jeannot, Danièle Guillemot. French public management reform: an evaluation. International Journal of Public Sector Management, 2013, 26 (4), pp.283-297. 10.1108/IJPSM-04-2012-0047 . hal00835206

\section{HAL Id: hal-00835206 \\ https://hal-enpc.archives-ouvertes.fr/hal-00835206}

Submitted on 11 Jul 2013

HAL is a multi-disciplinary open access archive for the deposit and dissemination of scientific research documents, whether they are published or not. The documents may come from teaching and research institutions in France or abroad, or from public or private research centers.
L'archive ouverte pluridisciplinaire $\mathbf{H A L}$, est destinée au dépôt et à la diffusion de documents scientifiques de niveau recherche, publiés ou non, émanant des établissements d'enseignement et de recherche français ou étrangers, des laboratoires publics ou privés. 
French public management reform: an evaluation

Gilles Jeannot, Danièle Guillemot

International journal of public sector management, vol $26, n^{\circ} 4,2013$, p. 283-297

Comparative research depicts France as somewhat of a laggard in terms of commitment to reform and its related impacts ${ }^{1}$. And although the idea of a cherished French exception does not really stand up to scrutiny (Rouban, 1995), the convergence with other countries appears not fully accomplished (Gualmini, 2007, Kuhlmann, 2010). Bouckaert and Pollitt (2004) classify French reforms alongside those carried out in a number of continental European countries that have favoured modernisation of management practices over any all-out market-driven approach to reform. Behind shared opposition in principle to certain New Public Management precepts (especially benchmarking with the private sector or performance-related pay), Cole and Jones (2005) note the de facto delegation of certain responsibilities, especially in the Ministry for Public Works. Kikert (2010) underlines the opposition between a genuine desire to reform and the no less real reactive capacities of public servants. Rouban stresses the absence of any basic doctrine for guiding reforms but recognises that the related changes have occurred via new program-based budgeting

1 "COI Changement organisationnel et informatisation" Survey of organisational change and computerisation) was funded by the statistical departement of the French Labour ministry (DARES) and by the Directorate General for administration of the French public service (DGAFP). The "enterprise" program of the Agence nationale de la recherché (ANR French national research agency) helped with data processing. 
techniques (Rouban, 2008). But while all of this research does assess the progress of reforms, its overriding aim is to analyse the specific features of the French context that underpin this intermediary position, i.e., i) the relative autonomy of the elite corps of French public servants ii) their very close links with elected representatives and the private sector, and iii) the marked support for public administration and public services among the population as a whole. Dreyfus (2000) insists on the importance of the French civil service characteristics and Chevallier (1996) outlines the role of administrative law only progressively hybridised by private management. Hayward and Thoenig have consistently underlined the fact that French state administration is not exactly a weberian bureaucracy: real power lies in local operational branches, and this impacts managerial change (Hayward, 1983) (Hayward, Wright, 2003) (Dupuy, Thoenig, 1983), (Thoenig, 2005).

Regarding the impact of reform, the tone of French research has changed over time. A series of mostly positive observations vis-à-vis the first attempts at overhauling public administration in the early 1990 s - especially in the Politiques et management public journal - were followed a few years later by an overall impression that reforms had got bogged down. Comments considering that the glass was either half-full or half-empty ranged from a certain disappointment (Gibert and Thoenig, 1993) to an impression of relative flexibility (Pallez, 1999). More recently, Scholars have supported the idea of a discrete change through management instruments or use of indicators (Bartoli, 2007) (Bezes, 2007), even before the effective implementation of program-based budgeting $(2006)^{2}$ and an institutional reorganisation drive, particularly the merger of central government, regional and department level services (2007).

\footnotetext{
2 Implementation of program-based budgeting and financial indicators began in 2007
} (Révision générale des politiques publiques) (Bezes, 2009). It was approved in 2000 as part 
Research, both comparative as well as French-led converge in considering French reform as modernisation (Bouckaert, Politt, 2004) through importation of management methods from the private sector, but it is still difficult to gauge the extent of any changes attributed to reform as a major systematic quantitative survey of public management practices or public sector administrative reform in general is yet to be carried out. The aim of this article is to put forward quantitative findings based on results of an original survey and to interpret results in relation with different periods of reform.

The survey: "Organisational Change and Computerisation" ("Changement organisationnel et informatisation" (COI), brings factual data(1) on above-mentionned subjects through measuring of dissemination of management instruments. The survey framework fully corresponds to the project of evaluating a reform, based on management method transfer. Data show a relative effectiveness of reform, measured through use of management instruments (especially for consumer relations). (2) However, we note major variations between different ministries that illustrate different reform processes at work. The components of this "snapshot" of French reform become clearer once placed in the context of successive reform cycles allowing to assess their overall dynamic (3). The monograph focuses on a substantive administrative body (2,4 million public servants) and contributes to a better understanding of reforms in countries which have undergone similar modernization reforms.

of the Finance Law (Loi organique sur les lois de finances), and first impacted the 2006 Budget. 


\section{1) Data and methods}

There is still a relative paucity of surveys that measure the actual dissemination of new public sector administrative practices in Europe and their impact on how government departments work (Politt, 1995), (Boyne et al., 2003), (Politt, Sorin, 2011) . In the US, processes for assessing public sector administrative practices have a longer history and they have focused on specific public vs. private sector differences, or an analysis of what actually drives performance (Rainey, Bozeman, 2000) (Moynihan, Pandey, 2005) (Brudney et al., 1999). Regarding France, with the exception of a number of older studies (Poinsard, 1987, Rangeon, 1992), only oversight issues have been dealt with on a regular basis in quantitative research. One study conducted during the first period demonstrated how middle management supported the reform (against the wishes of public sector mandarins) (Rouban, 1992). Two subsequent studies conducted in a trade union context analysed the extent to which public sector management practices had been brought into line with those in the private sector and how this phenomenon was less marked in central government departments than in state-owned enterprises (Karvar, Rouban, 2004; Desmarais, Abord de Chatillon, 2008). Finally, a more recent study commissioned by a trade union (CFDT, 2010) points up management unease in the wake of the organisational makeovers carried out after 2007.

The COI survey (Greenan, Mairesse, 2006) provides for the first time a quantitative assessment of the dissemination of a certain number of public sector administrative practices. This survey is intended to measure actual practices rather than opinions concerning these practices. It tries to grasp management practices through the use of what we may call "management instruments" (Vakkuri, 2010) or "process innovations" 
(Damanpour et al. 2009). For example, the use of quality charters, satisfaction questionnaires or one stop shop stands for consumer orientation, job opportunities bulletin board or strategic workforce planning stand for human resource orientation. This survey is close to other European monographs (Laegreid et al. 2006, Kuhlmann 2008, Torres et al. 2005)).

Using management tool lists to measure management practice is an imperfect method. As a matter of fact, actors may overestimate changes in management practices and organisations have been have been considered hypocritical (Brunson, 1982) in seeking legitimacy by slavishly imitating the most widely used practices (Di Maggio, Powel, 1983). This quest for conformity may especially apply to the public sector importing management methods from the private sector (Ashworth, Boyne and Delbridge, 2009, Feller, 1981). Nevertheless we cannot conclude that there is no link at all between declaration of use of management instrument and effective practice. Empirical studies show correlations between such declaration and performance (even if often indirectly) (Boyne, Walker, 2002), (Baer Frese, 2003), (Walker, Damanpour, Devece, 2011) which wouldn't have appeared if it was pure discourse. Management tool declaration is then surely a mixture between real practice and recognised legitimacy of a specific management orientation. Thus, even if it didn't reflect directly real practice it remains relevant to use comparisons between different management orientations, by tool categories (are HR tools more used/legitimate than quality tools ?) or along Ministries. 


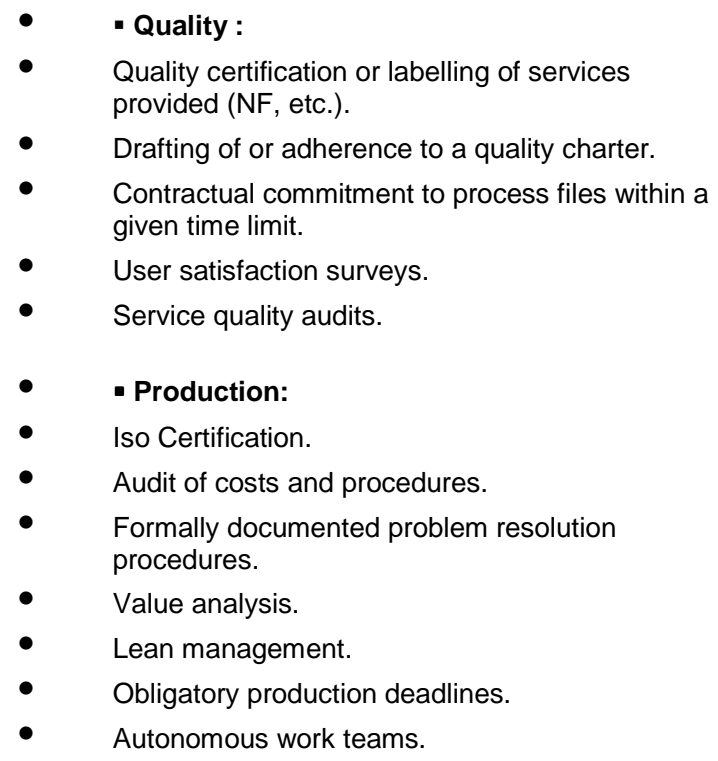

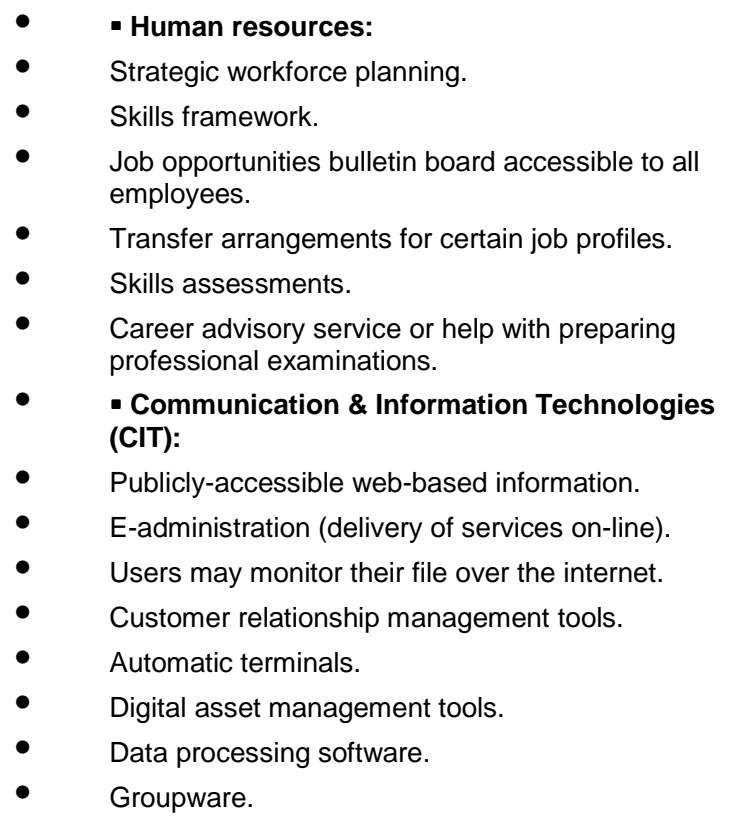

- Human resources:

- $\quad$ Strategic workforce planning.

- Skills framework.

- Job opportunities bulletin board accessible to all employees

- $\quad$ Transfer arrangements for certain job profiles.

Skills assessments. professional examinations. (CIT):

- Publicly-accessible web-based information

- $\quad$ E-administration (delivery of services on-line)

- Users may monitor their file over the internet.

- $\quad$ Customer relationship management tools.

- $\quad$ Automatic terminals.

- Digital asset management tools

- Groupware.

The scope of the survey is state administration including Parisian Departments and local units (Département and Régions), excluding the Ministry of defence. The survey (employers section) draws on a representative sample of units to measure management practices. These units have been defined as the first level of finance-related decisionmaking, for example a central ministry directorate, a regional ministry directorate or a School. The survey respondents were senior managers in the units in question.

The samples was compiled by INSEE, the French National Institute of Statistics and Economic Studies. It was conducted by post. The response rate is very high (80\%) as participation was obligatory $(\mathrm{N}=298)$. Statistical distortion due to sampling techniques and non responses are known and they have been corrected by weighting. This guarantees the representativeness of the survey. The questionnaire was launched in 2007, but 
Departmental heads were also asked questions about management instruments used in 2003.

\section{2) Changes in French public sector administrative practices}

The French public sector is by no means immobile in the face of changing management practices and modern techniques developed in the private sector have been extensively adopted. Nearly three-quarters of all management structures use new HR management instruments and the standard of IT equipment is high (table 1) and even better than in the private sector (Guillemot, Perrin, 2010).

Table 1: Equipment rate by application category (summary indicators) - (in \%)

\begin{tabular}{|c|c|c|c|c|c|c|}
\hline \multirow{2}{*}{\multicolumn{2}{|c|}{ Ministry }} & \multicolumn{5}{|c|}{ Type of application } \\
\hline & & quality & production & CIT & HR & Total \\
\hline \multirow[t]{2}{*}{ Education } & 2007 & 26 & 15 & 38 & 63 & 36 \\
\hline & 2003 & 9 & 10 & 24 & 47 & 23 \\
\hline \multirow{2}{*}{$\begin{array}{c}\text { General } \\
\text { administration }\end{array}$} & 2007 & 37 & 13 & 41 & 76 & 42 \\
\hline & 2003 & 18 & 9 & 25 & 56 & 27 \\
\hline \multirow{2}{*}{ Finance } & 2007 & 79 & 54 & 56 & 73 & 63 \\
\hline & 2003 & 42 & 36 & 32 & 48 & 38 \\
\hline \multirow{2}{*}{$\begin{array}{c}\text { Public Works and } \\
\text { Agriculture }\end{array}$} & 2007 & 52 & 33 & 41 & 84 & 51 \\
\hline & 2003 & 20 & 24 & 20 & 65 & 30 \\
\hline \multirow{2}{*}{ Police } & 2007 & 36 & 19 & 23 & 69 & 34 \\
\hline & 2003 & 23 & 13 & 16 & 56 & 25 \\
\hline \multirow{2}{*}{ Overall } & 2007 & 44 & 25 & 42 & 72 & 45 \\
\hline & 2003 & 21 & 17 & 25 & 54 & 29 \\
\hline
\end{tabular}

Explanation: a figure of $100 \%$ for a given ministry indicates that all of its departments use all of the management instruments in categories as defined in appendix 1

Source: COI-FP survey, employers section, 2007, CEE and DGAFP. Weighted data.

The general prevalence of objectives, dashboards and the small number of services affected by competition from the private sector or which have been tendered out to the private sector would appear to confirm the view of Bouckaert and Pollitt (2004) of a reform which, in France as in other continental European countries, is based more on overhauling 
management practices rather than on benchmarking of market practices (table 2). This must be nevertheless qualified by a pretty high level of public private partnerships and service concession agreements. We can also note the importance of inter-departmental partnerships arrangements (joined-up government often associated with post NPM models, (Christensen, Lagreid, 2007)) especially in the Ministries of public works and agriculture.

Table 2. Limited benchmarking to market practices.

\begin{tabular}{|l|c|c|c|c|c|}
\hline $\begin{array}{l}\text { Management } \\
\text { structures declaring } \\
\text { that they have } \\
\text { recourse to (\%) }\end{array}$ & $\begin{array}{c}\text { inter- } \\
\text { departmental } \\
\text { partnership } \\
\text { arrangements }\end{array}$ & $\begin{array}{c}\text { Contracted } \\
\text { objectives }\end{array}$ & PPPs & $\begin{array}{c}\text { contracting } \\
\text { service } \\
\text { concession } \\
\text { arrangements }\end{array}$ & $\begin{array}{c}\text { services out to } \\
\text { the private } \\
\text { sector (since } \\
\text { 2003) }\end{array}$ \\
\hline Education & 77 & 56 & 36 & 15 & 1 \\
\hline $\begin{array}{l}\text { General } \\
\text { administration }\end{array}$ & 79 & 23 & 47 & 26 & 4 \\
\hline Finance & 83 & 96 & 24 & 1 & 14 \\
\hline $\begin{array}{l}\text { Public Works and } \\
\text { Agriculture }\end{array}$ & 95 & 44 & 30 & 24 & 21 \\
\hline Police & 67 & 37 & 39 & 2 & 18 \\
\hline Overall & 82 & 51 & 36 & 16 & 9 \\
\hline
\end{tabular}

Source: COI-FP survey, employers section, 2007, CEE and DGAFP. Weighted data.

Although the public sector is less well-equipped than the private sector with more technical instruments for organising productivity or commitments to quality, it makes very extensive use of devices designed to enhance user relations by using communications (publication of activity bulletins), by making services easier to use (one-stop shops, access to personal files via internet [e-administration]), or via service commitments (e.g., the Marianne charter containing guarantees on how users should be treated, minimum response times for processing files, etc.) [Table 3]. This transformation of user contact situations concerns in particular the implementation of regulations (taxes, administrative authorisations, etc.). The level of commitment would appear to be eminently comparable with that observed in German local government services (Kuhlmann et al., 2008). All of these innovations were 
deployed in the early 1990 s in public utilities that held monopoly positions at that time, such as the post office, railways, the Paris métro or electricity distribution (Jeannot, 2006).

Table 3: Instrumentation of citizen/customer relations.

\begin{tabular}{|l|c|c|c|c|c|c|c|}
\hline $\begin{array}{l}\text { Management } \\
\text { structures } \\
\text { declaring that } \\
\text { they have } \\
\text { recourse to } \\
(\%)\end{array}$ & $\begin{array}{c}\text { Published } \\
\text { activity } \\
\text { bulletins }\end{array}$ & $\begin{array}{c}\text { One-stop } \\
\text { shops }\end{array}$ & $\begin{array}{c}\text { Quality } \\
\text { charters }\end{array}$ & $\begin{array}{c}\text { Minimum } \\
\text { response } \\
\text { times }\end{array}$ & $\begin{array}{c}\text { User } \\
\text { satisfaction } \\
\text { surveys }\end{array}$ & $\begin{array}{c}\text { E- } \\
\text { administration }\end{array}$ & $\begin{array}{c}\text { ISO-type } \\
\text { quality } \\
\text { certification }\end{array}$ \\
\hline Education & 69 & 8 & 37 & 19 & 46 & 59 & 10 \\
\hline $\begin{array}{l}\text { General } \\
\text { administratio } \\
\text { n }\end{array}$ & 64 & 30 & 78 & 39 & 26 & 48 & 4 \\
\hline Finance & 74 & 55 & 75 & 72 & 76 & 74 & 53 \\
\hline $\begin{array}{l}\text { Public Works } \\
\text { and } \\
\text { Agriculture }\end{array}$ & 64 & 27 & 83 & 60 & 59 & 49 & 39 \\
\hline Police & 67 & 11 & 54 & 34 & 35 & 7 & 8 \\
\hline Overall & 68 & 27 & 65 & 43 & 48 & 53 & 22 \\
\hline
\end{tabular}

Source: COI-FP survey, employers section, 2007, CEE and DGAFP. Weighted data.

Human resource management instruments are largely disseminated but occupy a peculiar position. If there is a positive correlation between all indicators which points up a relatively uniform trend towards modernisation to which departments have committed to a greater or lesser degree, there is a lower correlation between HR and other management instruments (excluding IT applications) (table 4).

Table 4: the singular position of HR management instruments.

\begin{tabular}{|c|c|c|c|c|}
\hline $\begin{array}{c}\text { Spearman partial } \\
\text { correlation } \\
\text { coefficients }\end{array}$ & $\begin{array}{c}\text { HR instrument } \\
\text { summary } \\
\text { indicator }\end{array}$ & $\begin{array}{c}\text { Production } \\
\text { instrument } \\
\text { summary } \\
\text { indicator }\end{array}$ & $\begin{array}{c}\text { Quality } \\
\text { management } \\
\text { instrument } \\
\text { summary } \\
\text { indicator }\end{array}$ & $\begin{array}{c}\text { ICT instrument } \\
\text { summary } \\
\text { indicator }\end{array}$ \\
\hline $\begin{array}{c}\text { HR instrument } \\
\text { summary } \\
\text { indicator }\end{array}$ & 1.00 & $0.19^{* * *}$ & $0.13^{* *}$ & $0.36^{* * *}$ \\
\hline $\begin{array}{c}\text { Production } \\
\text { instrument } \\
\text { summary } \\
\text { indicator }\end{array}$ & & 1.00 & $0.28^{* * *}$ & $0.34^{* * *}$ \\
\hline $\begin{array}{c}\text { Quality } \\
\text { management } \\
\text { instrument } \\
\text { summary } \\
\text { indicator }\end{array}$ & & & 1.00 & $0.34^{* * *}$ \\
\hline
\end{tabular}

Explanation: probability $*<0.1, * *<0.05 * * *<0.01$

Source: COI-FP survey, employers section, 2007, CEE and DGAFP. 
But the deployment of these tools has been far from trouble-free and the survey demonstrates this through questions that focus specifically on new program-based budgeting procedures $(L O L F)$ (Table 5). In particular, we note that although departmental heads in the Ministry of Finance - which played a leading role in this reform - claimed that problems were related to employee adaptation only, departmental heads in other ministries clearly identified problems in defining indicators and achieving a fit between management of personnel by corps and by ministry and programme-based initiatives. This measure of implementation difficulties combines with qualitative observations concerning the definition of indicators that are all too often disconnected from the initiative to be carried out (Brunetière, 2006) or the complexity of managing personnel in the context (Debar, 2010).

Table 5. Difficulties in implementing program-based budgeting (LOLF).

\begin{tabular}{|l|c|c|c|c|c|}
\hline $\begin{array}{l}\text { When implementing } \\
\text { budgeting), management } \\
\text { declared that they } \\
\text { encountered (\%) }\end{array}$ & $\begin{array}{c}\text { personnel } \\
\text { management } \\
\text { difficulties }\end{array}$ & $\begin{array}{c}\text { problems with } \\
\text { employee } \\
\text { adaptation }\end{array}$ & $\begin{array}{c}\text { internal } \\
\text { conflict }\end{array}$ & $\begin{array}{c}\text { incompatibility } \\
\text { problems } \\
\text { defining } \\
\text { indicators }\end{array}$ & $\begin{array}{c}\text { management of } \\
\text { human resources } \\
\text { and corps } \\
\text { system }\end{array}$ \\
\hline Education & 10 & 12 & 1 & 47 & 12 \\
\hline General administration & 39 & 51 & 7 & 66 & 29 \\
\hline Finance & 13 & 72 & 0 & 12 & 7 \\
\hline $\begin{array}{l}\text { Public Works and } \\
\text { Agriculture }\end{array}$ & 35 & 58 & 1 & 71 & 28 \\
\hline Police & 36 & 39 & 7 & 32 & 9 \\
\hline Overall & 25 & 43 & 2 & 49 & 18 \\
\hline
\end{tabular}

Source: COI-FP survey, employers section, 2007, CEE and DGAFP. Weighted data.

The overall picture depicted in this table needs to be qualified in the light of different tendencies in different ministries. The first observation that needs to be stressed is that the overall equipment rate is much higher in the Ministry of Finance and much lower in the police and the Ministry of Education. Out of the list of 28 instruments (see list appendix 1), departments within the Ministry of Finance stated that they used two-thirds on average, 
departments in the ministries of Public Works and Agriculture about half, while the police and departments in the Ministry of Education declared that they use barely one-third. The lower equipment rate in these latter government departments may be partially attributable to the small size of some of their components such as lycées or police stations. In the private sector, company size is the primary explanatory factor for differing equipment ratios (Guillemot, Kocoglu, 2010). However, we should note that for web-based technologies (provision of web-based services, on-line consultation of user files, etc.), the Ministry of Education lies in second place which reflects the widespread use of these instruments for handling relations with both the public (pupils, students, etc.) and employees (teachers).

A comparison with the period since 2003 highlights a significant upward trend, possibly buoyed by inter-ministerial "modernization strategies" which kicked off post-2003. For each of the instruments listed, users were asked if the instrument was present today (in 2007) and in 2003. The degree of accuracy is surely lower for the 2003 data inasmuch as it is contingent on respondents' memories. The Ministry of Finance, which had a higher equipment ratio than the other ministries, maintained its lead. This is related to a series of reforms that it launched in the early 2000s, particularly the deployment of shared software for processing fiscal data in the wake of an unsuccessful attempt to merge a number of different departments within the Ministry.

Public works and Agriculture Ministries specificity is linked to human resource as this is the only instance in which the supremacy of the Ministry of Finance does not prevail. Differences between these ministries and the Finance Ministry may be refined by a detailed analysis based on the responses by the management heads to supplementary questions 
(table 6, these questions were not included in the "instrument list" (appendix 1 for table 1) as they indicate more the actual practice rather than the sheer possession of a management instruments) Employee appraisals are now standard practice throughout virtually the entire French civil service based on routine, mandatory procedures. However, professional evaluations for public servants under contract, which are not routinely performed because employment conditions may vary considerably and thus require a commitment on the part of a given departmental head, are more frequent in the ministries of Public Works and Agriculture. Moreover, we may clearly distinguish between two bases of pay differential: the first clearly corresponds to the performance-related pay model while the second - more "open" - notion differentiates employees more on the basis of their attitude (bonus based on an employee's individual commitment or how the employee serves the entity). The results clearly highlight three groups of respondents: (i) those for which performance-related pay is used, very prevalent in the Ministry of Finance and in the police where Nicolas Sarkozy made widespread use of this instrument when he was Minister of the Interior; (ii) a group for which no basis of differentiation is used, particularly in the Ministry for Education; and (iii) government departments that favour an employee's individual commitment /effort-type model. The latter approach, which does not differentiate between employees on the basis of performance alone, is especially widely used in the ministries of Public Works and Agriculture. It reflects a difference in attitudes, especially vis-à-vis the Ministry for Finance, as well as slightly more developed HR practices in this area. 
Table 6: differentiated HR practices.

\begin{tabular}{|l|c|c|c|c|c|c|}
\hline $\begin{array}{l}\text { Management } \\
\text { structures declaring } \\
\text { that they have } \\
\text { recourse to (\%) }\end{array}$ & $\begin{array}{c}\text { Employee } \\
\text { appraisals }\end{array}$ & $\begin{array}{c}\text { Appraisals for } \\
\text { public servants } \\
\text { under contract }\end{array}$ & $\begin{array}{c}\text { Strategic } \\
\text { workforce } \\
\text { planning }\end{array}$ & $\begin{array}{c}\text { Skills } \\
\text { assessments }\end{array}$ & $\begin{array}{c}\text { Performance- } \\
\text { related } \\
\text { bonuses }\end{array}$ & $\begin{array}{c}\text { Bonuses } \\
\text { based on } \\
\text { employee } \\
\text { commitm } \\
\text { ent }\end{array}$ \\
\hline Education & 94 & 45 & 27 & 52 & 16 & 32 \\
\hline $\begin{array}{l}\text { General } \\
\text { administration }\end{array}$ & 94 & 43 & 54 & 53 & 34 & 62 \\
\hline Finance & 100 & 47 & 73 & 79 & 96 & 25 \\
\hline $\begin{array}{l}\text { Public Works and } \\
\text { Agriculture }\end{array}$ & 99 & 81 & 72 & 89 & 44 & 68 \\
\hline Police & 77 & 18 & 26 & 50 & 76 & 67 \\
\hline Overall & 95 & 51 & 52 & 64 & 45 & 48 \\
\hline
\end{tabular}

Source: COI-FP survey, employers section, 2007, CEE and DGAFP.

\section{3) Discussion: change in policy context}

The COI surveys findings highlight two major features of management in the French state administration. First, we note the very widespread use of management instruments to structure departmental services and in particular, relations with service users. They also measure the impact on employees via codified work practices that are pretty much in line with those found in the private sector. This transformation in management practices, coupled with relatively low levels of responses to questions referring to benchmarking of market practices, is roughly in line with the continental model described by Bouckaert and Pollitt (2004). Second, differentiation of employees and performance-related pay in particular is much less prevalent than in the private sector and although several different models can be identified (see below), inter-ministerial differences are less marked than the differences between the public and private sectors as a whole. It is striking to compare this finding with the high rate of dissemination of certain HR management instruments such as appraisal interviews or career management instruments. The gap between the malleability of management practices on the one hand, and the large degree of stability concerning the scope of human resources on the other, has been observed in other countries (Emery and 
Giauque, 2007) (Kirkpatrick and Hoque, 2005). This concord with older results on maintained difference for Human ressource management in public organisations in United States (Rayney, Bozeman, 2000) (Brudney et al. 2000).

Within these general trends, the second contribution of the surveys is to highlight significant variations between ministries. These variations correspond to successive reform models.

The first model was forged around the public service renewal programme of 1989 sponsored by the Socialist Prime Minister, Michel Rocard. The ground had already been prepared by the quality-based initiatives deployed by the conservative and socialist governments headed by Edouard Balladur and Laurent Fabius, respectively. This first model was based on allowing local managers (particularly the heads of regional and departmental services) greater room for initiative, as well as a focus on employee mobilisation. As it focused particularly on human resources issues and decentralised decision-making, it contrasted sharply with developments in the UK over the same period. Most observers agree that circa 1990 the Ministry of Public Works was the key testing ground for new management methods, such as the quality circles and service-related projects. An analysis of the articles that appeared in the journal Politiques et management public is particularly instructive in this regard: seven of the fourteen articles dealing with the implementation of these new practices between 1989 and 1993 focused on this Ministry. It was the fruits of this model that were being debated in the late 1990s between those who maintained that the process had run out of steam and those who contended that it had been a quiet success. Listing the human resources instruments deployed in these pilot ministries highlights the continuation not just of higher usage rates for these types of 
instruments, but signs of differing attitudes in the choice of such instruments. Measuring such differences 15 years after the innovations were first implemented helps to limit the disillusionment of certain observers. The Ministries the most influenced by this first model remain in advance for the possession of HR instruments.

The second model has emerged with the consensual vote for a reform of government budgeting procedures which introduced the use of both program-based budgeting and financial indicators first impacted the 2006 Budget (Bezes, 2009). After 2000 and the approval of budgetary reform, it was the Ministry for the Economy and Finance that moved to the forefront of administrative reform. This central role was bolstered by the fact that the body tasked with spearheading reform, the Directorate for State Modernisation (DGME) and the former Ministry for the Public Service had now all been subsumed into the Ministry for Finance. The survey shows that developments related to this model pre-date new program-based budgeting techniques $(L O L F)$ first implemented in 2006. The Ministry of Finance has actively developed a whole range of management instruments involving inter alia standards of quality and e-administration.

Public management reform must also be examined in France in the light of relations between local and central units of ministries (Hayward, 1983) (Dupuy, Thoenig, 1983). Unfortunately the COI questionnaire gives little relevant data on this subject. Somehow we could consider that a lot of management instruments include reporting dimensions and then more control opportunities. But it is difficult to measure to what extent these opportunities will be used by central directions to monitor regional or departmental units, or by local unit managers to control their own staff. In the case of Lolf performance indicators, the answers on use conditions (table 5) show that managers (who are in large majority local managers in 
the sample) express difficulties in all ministries except in the Finance ministry. Could this be interpreted as a sign of reluctance or defiance in front of this new form of control ? If it is the case, the classical (centre/periphery) main question must include the relationship with the leading ministry of the reform.

The survey was conducted in 2007 before Nicolas Sarkozi's government launched an institutional reorganisation drive (particularly the merger of central government, regional and department level services) as part of a general public policy makeover (Révision générale des politiques publiques, RGPP) and diverse measures against civil service status. These decisions have reinforced previous trends, however their impact still need to be evaluated.

\section{Conclusion}

The Continental European reform model based on modernization (Bouckaert, Pollitt, 2000) is not synonymous with inaction. The level of dissemination of process innovations is high, even though, we must remain cautious regarding the possible gap between questionnaire responses and real practices. As observed in many countries, human resource change seems more difficult than change in quality methods or user's orientation implementation. This transformation however varies from one Ministry to the other. The characteristics of the present discrepancies between the Ministries correspond to the policies lead successively in each of the Ministries. Three decades later, the early 90's decentralization and empowerment-oriented reform model has left footprints after on the public works and agricultural Ministries where they were primarily implemented. Another reform model based on wide dissemination and use of work monitoring instruments has spread across the 
Finance Ministry since 2000. These discrepancies suggest on the one hand that modernization can include different orientations and on the other hand that French public management reform has been anchored in a long period change.

\section{References}

Ashworth R., Boyne G. A., Delbridge R. (2009), "Escape from iron cage ? Organizational change and isomorphic pressures in the public sector", Journal of public administration research and theory, 19:165-187.

Baer Markus Frese Michael (2003) "Innovation is not enough: climate change for initiative and psychological safety, process innovations, and firm performance", Journal of organizational Behavior", vol 24 p. 45-68

Bartoli A. (2007), "Les outils du management public, fausses pistes et vrai défi" in: Huron D., Spindler J., Le management public en mutation, L'Harmattan.

Bezes P. (2007),.’The hidden politics of administrative reform: cutting French civil service wages with a low-profile instrument”, Governance, vol. 20, n¹, p. 23-56.

Bezes P. (2009), Réinventer l'Etat, Les réformes de l'administration française (1962-2008), Puf.

Bouckaert G., Pollitt C (2004), Public management reform: a comparative analysis (second edition), Oxford university press.

Boyne G. A., Farrell C., et al. (2003) Evaluating public management reforms, Buckingham, open university press.

Boyne, George A., and Richard M. Walker. 2002. Total quality management and performance: An evaluation of the evidence and lessons for research on public organizations. Public Performance and Management Review 26:111-31. 
Brudney J. 1., Hebert T., Wright D. S. (1999), "Reinventing government in the American States; Measuring and explaining administrative reform", Public administration review, vol $59, \mathrm{n}^{\circ} 1 \mathrm{p} 19-30$.

Brunetière J. R. (2006), "Les indicateurs de la loi organique sur les lois de finances (LOLF), une occasion de débat démocratique?", Revue française d'administration publique, $\mathrm{n}^{\circ} 117$, p. 95-111.

Brunsson N. (1982), The organization of Hypocrizy, The decision and action in organizations, John Wiley and son.

Brunsson N. (1982), The organization of Hypocrizy, The decision and action in organizations, John Wiley and son.

CFDT (2010), Cadres des fonctions publiques, les resultats de l'enquête.

Chevallier J. (1996), "Public administration in statist France", Public administration review, vol 56, $\mathrm{n}^{\circ} 1, \mathrm{p} .67-74$

Christensen T., Laegreid P. (2007), Transcending new public management, the transformation of public sector reforms, Aldershot, Ashagate.

Cole Alistair, Jones Glyn (2005), "Reshaping the state: administrative reform and new public management in France", Governance, vol 18, n 4, p 567-588.

Damanpour F., Walker R. M., Avellaneda C. N. (2009), “Combinative effects of innovation types and organizational performance: a longitudinal study of service organizations", Journal of management studies, vol 46, $\mathrm{n}^{\circ} 4$, p. 650-675.

Debar Anne (2010), “La gestion des hommes dans l'administration territoriale de l'Etat. Entre bricolage gestionnaire et travail sur le sens", Revue française d'administration publique, $\mathrm{n}^{\circ} 132$, p. 757-770. 
Desmarais Céline, Abord de Chatillon Emmanuel (2008), “existe-t-il encore des différences entre le travail des managers du public et ceux du privé ?", Revue française d'administration publique, $\mathrm{n}^{\circ} 128$, p. 767-783.

DiMaggio, Paul J., and Walter W. Powell. 1983. "The iron cage revisited: Institutional isomprohism and collective rationality in organizational fields." American Sociological Review 48:147-60.

Dreyfus F. (2000), L’invention de la bureaucratie: servir l'Etat en France en Grande Bretagne et aux Etats-Unis, La découverte.

Dupuy F. Thoenig J.-C. (1983), Sociologie de l'administration française, Armand Colin.

Giauque D. (2003), "New public management and organizational regulation, the liberal bureaucracy", International review of administrative sciences, vol 69, p. 567-592.

Gibert P., Thoenig J. C. (1993), “La gestion publique: entre l'apprentissage et l'amnésie”, Politiques et management public, vol 11, n 1, p. 3-21.

Green F. (2004), "Why had work effort become more intense ?", Industrial relations, vol $43, \mathrm{n}^{\circ} 4, \mathrm{p} .709-741$.

Greenan N., Mairesse J. (dir.) (2006), "Réorganisations, changements du travail et renouvellement des compétences", Revue économique, vol. 57, n 6, novembre p. 1177, 1203

Gualmini Elisabetta (2007), "Restructuring weberian bureaucracy: comparing managerial reforms in Europe and the united states, Public administration, p. 75-94.

Guillemot D. et Kocoglu Y. (2010), "La diffusion des outils dans les entreprises françaises, une approche synthétique", Réseaux, vol 28 -162 p. 167-198.

Guillemot D., Peyrin A. (2010), «Les salariés de plus de 50 ans et l'informatique, une comparaison public privé », Economie et statistiques, n 437, 2010, p. 3-28. 
Hayward JES (1983), Governing France. The One and the Indivisible Republic, London, Weindenfield and Nicolson.

Hayward JES. Wright V. (2003), Governing from the centre: core executive coordination in France, Oxford university press.

Hoggett Paul (1996), "New modes of control in the public service", Public administration, vol 74, p. 9-32.

Jeannot G. (2006) "Diffusing values or adjusting practices? A review of research on French public utilities", International Journal of Public Sector Management, Vol. 19, n 6 , pp.598- 608

Jeannot G; Rouban L. (2010), “Changer la fonction publique”, Revue française d'administration publique, $\mathrm{n}^{\circ} 132$, p. 665-672.

Jettinghoff K. Houtman I. (1999), A sector perspective on working conditions, European foundation for the improvement of living and working conditions.

Karvar Anousheh, Rouban Luc, Les cadres au travail, les nouvelles règles du jeu, Paris, La découverte, 2004.

Kikert W.J.M. "Public management reform Continental Europe: National distingtiveness" in Christensen T., Laegreid P., The Ashgate Research companion to New public management, Ashgate, 2010.

Kirkpatrick Ian, Hoque (2005), “The decentralisation of employment relations in the british public sector”, Industrial relations journal; vol 36, n², p. 100-120.

Kuhlmann S. (2010), "Performance measurement in european local governments: a comparative analysis of reform experiences in Great Britain, France, Sweden, and Germany", International review of administrative sciences, vol 76, $\mathrm{n}^{\circ} 2$, p. 331-344. 
Kuhlmann S., Bogumil J., et al. (2008), "Evaluating administrative modernization in German local government: success or failure of the new steering model", Public administration review, vol 68, $\mathrm{n}^{\circ} 5$, p. 851-863.

Laegreid P. Roness P. Rubecksen K. (2006), "Performance management in practice: The norvegian way"? Financial accountability and management, August, p. 251-270.

Le Galès P., Scott A. (2008), «une révolution bureaucratique britannique ? », Revue française de sociologie, vol 49, $\mathrm{n}^{\circ}$ 2, p. 301-330.

Minvielle E. (2006), "New public management à la française: the case of regional hospital agencies”, Public administration review, vol. 66, n 5, p. 753-763.

Moynihan D, Pandey S. (2005), «Testing how management matters in an era of government by performance management », Journal of public management research and theory, vol 15, n 3, p. 421-439.

p3.

Pallez F. (1999), “Les souplesses cachées du mammouth”, Le journal de l’Ecole de Paris, Poinsard R. (1987), “La modernisation de la gestion administrative: un bilan”, Politiques et management public, vol5 $\mathrm{n}^{\circ} 2$, p. 21-63.

Politt C., Sorin D., (2011) "The impact of the new public management in Europe: A meta analysis", COCOPS working paper, Public management institute, Leuven.

Pollitt Christopher (1995), "Justification by faith or by works ? Evaluating new public management", Evaluation, vol 1, n 2, p. 133-154.

Rainey H.G., Bozeman B. (2000), “Comparing public and private organizations: empirical research and the power of a priori", Journal of public administration research and theory, vol 10, $\mathrm{n}^{\circ} 2$, p. $447-469$

Rangeon F. (1992), "la notation des fonctionnaires en question", Politiques et management public, vol10, $\mathrm{n}^{\circ} 2$, p. 193-211. 
Rouban L. (1992) “Enquête sur les projets de service”in : Serieyx H., Fraisse R., L'Etat dans tous ses projets, La documentation française, p. 187-234.

Rouban L. (2008), "Reform without doctrine: public management in France", International journal of public sector management, vol 21, $\mathrm{n}^{\circ} 2, \mathrm{p} .133-149$.

Rouban, L. (1995) 'Public Administration at the Crossroads: The End of the French Specificity?', in Harold W. Stanley and Richard G. Niemi (eds) Vital Statistics on American Politics, 5th edn, pp. 39-63. Washington, DC: Congressional Quarterly. Thoenig J.-C. (2005), "Territorial administration and political control: decentralization in France”, Public administration, vol. 83, n³., p. 685-708.

Torres Lourdes, Pina Vincente Royo Sonia (2005), E-government and the transformation of public administration in EU countries: Beyond NPM or just a scond wave of reforms? Documento de trabajo 2005-01 Faculdad de Ciencias economicas y empresariales. Universidad de Zaragoza, 33 p.

Vakkuri Jarmo (2010), "Struggling with ambiguity: public managers as users of NPMoriented management instruments", Public administration, vol 88, n4, p. 999-1024.

Feller, Ian. 1981. Public sector innovation as “conspicuous consumption. Policy Analysis $7: 1-20$.

Walker R. M., Damanpour F. Devece C. (2011), "Management innovation and organizational performance: the mediating effect of performance management", Journal of public management research and theory, 21:367-386. 